\title{
Naloxone Potentiates Epinephrine Release during Hypoxia in Fetal Sheep: Dose Response and Cardiovascular Effects
}

\author{
ALMA MARTINEZ, JAMES PADBURY, LISA SHAMES, CHRISTOPHER EVANS, AND \\ JAMES HUMME \\ Perinatal Research Laboratory, Department of Pediatrics, UCLA School of Medicine, Harbor-UCLA Medical \\ Center, Torrance, California 90509
}

\begin{abstract}
The effect of opiate receptor blockade on the plasma catecholamine response to hypoxemia was studied in seven chronically catheterized fetal lambs in utero. All animals underwent treatment with hypoxia alone, naloxone infusion alone $(2 \mathrm{mg} / \mathrm{kg})$ and hypoxia with naloxone at four different dosages $(0.1,0.5,1.0$, and $2.0 \mathrm{mg} / \mathrm{kg})$. Maternal and fetal hypoxia was maintained for $20 \mathrm{~min}$. There were no differences noted in the degree of hypoxemia or acidemia between the different hypoxia treatment groups. Hypoxia increased both norepinephrine and epinephrine plasma levels in all fetal sheep studied. We found a dose-dependent increase in plasma epinephrine levels in response to naloxone infusion during hypoxia. Plasma epinephrine level by $20 \mathrm{~min}$ of hypoxia with the $0.1 \mathrm{mg} / \mathrm{kg}$ naloxone dose (geometric mean $5366 \mathrm{pg} / \mathrm{ml}$ ) was significantly more than with hypoxia alone $(997 \mathrm{pg} / \mathrm{ml})$. Naloxone at the other doses did not alter the epinephrine responses. There was no augmentation of plasma norepinephrine levels by naloxone at any dose studied. Thus, naloxone augmented the plasma epinephrine response to hypoxia in fetal sheep suggesting that the opiate peptides act as modulators of the sympathoadrenal system. The naloxone dose response differences observed in this study suggest this modulation is largely by antagonism of $\mu$-receptors. (Pediatr Res 23: 343-347, 1988)
\end{abstract}

Abbreviations

ANOVA, analysis of variance

SNK, Student-Newman-Keuls test HR, heart rate

Marked increases in plasma catecholamines have been described in fetal and newborn animals in response to hypoxia (1), hypothermia (2), hemorrhage (3), labor (4), and birth $(5,6)$. Catecholamine release has been shown to be important for cardiovascular, pulmonary, and metabolic adjustments during neonatal adaptation to extrauterine life (7). In addition, the ability of neonatal rats to survive acute asphyxia depends on the release of catecholamines (8). The endogenous opiate peptides (enkephalins and endorphins) have also been postulated to func-

Received August 24, 1987; accepted November 20, 1987.

Correspondence James F. Padbury, M.D., Department of Pediatrics, HarborUCLA Medical Center, 1000 West Carson Street, Research Building 1, Torrance, CA 90509.

Supported by HD18014, HD22003, and Training Grant HD07013 from the National Institutes of Health and a Basil O'Connor Starter Research Grant from the National Foundation March of Dimes. tion as modulators of the cardiovascular response to stress. Circulating plasma levels of opiate peptides increase in response to hypoxia (9), asphyxia $(10,11)$, central nervous system hemorrhage (12), shock (13), and labor and delivery $(14,15)$. Opiate peptide antagonists have been shown to reverse cardiovascular collapse in hemorrhagic and endotoxin shock (16).

Neuropharmacologic studies suggest an important physiologic role for opiate peptides as modulators of sympathoadrenal activity. Opiate peptides inhibit neurotransmission in sympathetic ganglia $(17,18)$ as well as adrenal medullary catecholamine release in vitro (19) and in vivo (20). Endogenous opiates in the CNS also inhibit sympathoadrenal activity (21). We have recently demonstrated that pharmacologic blockade of endogenous opiate receptors is associated with an increase in catecholamine release at birth (22).

In order to extend these observations and to study the factors that regulate fetal catecholamine release during perinatal stress, we designed experiments to investigate the effect of endogenous opiate peptide blockade on plasma catecholamine release in fetal sheep in response to hypoxia.

\section{MATERIALS AND METHODS}

Surgical procedures. Seven time-dated pregnant ewes with singleton pregnancies were catheterized at 118-122 days of gestation (term 150 days). The ewes were sedated with ketamine $(800 \mathrm{mg})$ and atropine $(1.2 \mathrm{mg})$ and received a constant infusion of ketamine $(8-10 \mathrm{mg} / \mathrm{min})$ for the duration of the operation. The fetal hindlimb was exteriorized through a uterine incision and polyvinyl catheters were placed in an artery and vein after local anesthesia. The catheters were advanced to the level of the descending aorta and inferior cava, respectively. An additional catheter was placed in the uterus to allow measurement of amniotic fluid pressure. The uterine incision was closed with all catheters tunneled subcutaneously in the maternal flank and stored in a cloth pouch sewn to the skin of the ewe. The ewe had catheters placed into the femoral vein and artery. These were also tunneled subcutaneously and stored with the fetal catheters. Oxacillin and gentamycin were given intravenously for 3 days postoperatively to both mother and fetus. Animals were allowed to recover a minimum of 3-5 days before any studies were performed.

Experimental protocol. On the day of study, the fetal arterial catheter and intrauterine catheter were connected to Statham P23dB pressure transducers that were attached to a Sensormedics R611 rectilinear polygraph. Fetal arterial blood gas, hematocrit, fetal systolic blood pressure, mean blood pressure, and amniotic fluid pressure were observed for a minimum of $30 \mathrm{~min}$ before any experimental manipulation. At that time, fetal $\mathrm{HR}$ and blood pressure were recorded, and duplicate arterial blood samples 
were obtained for baseline catecholamine values and blood gas analyses. Fetal arterial pressures were corrected by subtracting amniotic fluid pressure. After obtaining the baseline samples, the experimental protocol commenced. All fetal sheep were randomly assigned the order in which they were studied. On separate days each fetus underwent saline infusion alone, naloxone alone $(2 \mathrm{mg} / \mathrm{kg})$, hypoxia alone, or hypoxia with naloxone infusion at $0.1,0.5,1.0$, and $2.0 \mathrm{mg} / \mathrm{kg}$. The naloxone infusions were given as an initial intravenous bolus $(\mathrm{mg} / \mathrm{kg})$ and then followed by a constant infusion at the same dose $(\mathrm{mg} / \mathrm{kg} / \mathrm{h})$. All animals underwent each protocol and were allowed to recover 1-2 days between studies. Fetal sheep were studied between 122 and 142 days of gestation (Table 1).

Hypoxia was produced by securing a clear plastic bag over the ewe's head and delivering a gas mixture of nitrogen and oxygen. The $\mathrm{FIO}_{2}$ of the inspired gas mixture was in the range of 10$12 \%$. The fetal $\mathrm{PaO}_{2}$ was monitored and oxygen delivery was adjusted to maintain hypoxemia in the range of $12-14 \mathrm{~mm} \mathrm{Hg}$ in the fetus.

Fetal arterial blood samples drawn after 10 and 20 min of hypoxia for measurements of plasma catecholamines were added to chilled test tubes containing EGTA and reduced glutathione. The samples were centrifuged immediately. The plasma was separated and stored at $-70^{\circ} \mathrm{C}$ until catecholamine analysis was performed. Plasma catecholamine concentrations were determined by radioenzymatic assay sensitive to $1-2$ pg of norepinephrine and epinephrine as previously described $(6,7,23)$. Arterial blood gases were recorded at each interval. Approximately $4 \mathrm{ml}$ of blood was removed at each sample period and replaced with heparinized maternal blood that had been drawn before any experimental manipulation. Fetal weight was estimated using a formula previously described for fetal sheep (24).

Data analysis. Norepinephrine and epinephrine levels were $\log$ transformed before statistical analysis. Plasma norepinephrine and epinephrine levels are expressed as geometric mean concentrations $(\mathrm{pg} / \mathrm{ml}) \pm$ SEM. Other data are presented as mean \pm SEM. ANOVA was used for comparisons between groups and statistical differences were determined using the SNK. Two-way ANOVA for repeated measures was used for comparison of plasma catecholamine values during hypoxia between the different treatment groups.

\section{RESULTS}

Baseline values for all fetuses for norepinephrine $(418 \pm 23 \mathrm{pg}$ $\mathrm{ml})$ and epinephrine $(9 \pm 2 \mathrm{pg} / \mathrm{ml}), \mathrm{HR}(157 \pm 5 \mathrm{bpm})$, systolic blood pressure $(77 \pm 1 \mathrm{~mm} \mathrm{Hg}), \mathrm{pH}(7.36 \pm 0.03)$, and $\mathrm{pO}_{2}(22$ $\pm 0.5 \mathrm{~mm} \mathrm{Hg}$ ) were similar to data previously reported by our laboratory and others $(1,4,7,22)$. All fetuses underwent each protocol. By allowing 1-2 days rest period between studies, we found that catecholamine levels, HR, and blood pressure on subsequent studies did not vary significantly and had returned to values found in unstressed animals (Table $1, p>0.05$, ANOVA). Also shown in Table 1, there was no statistical difference in gestational age of fetal sheep during each set of study protocols $(p>0.05$, ANOVA $)$

Control studies. When animals were treated with saline or naloxone alone $(2 \mathrm{mg} / \mathrm{kg})$, there were no significant changes in norepinephrine or epinephrine levels at 10 and $20 \mathrm{~min}$ when compared to baseline levels (Fig. 1). Naloxone or saline treatment alone did not affect fetal HR or blood pressure when compared with baseline values or each other (Table $2, p>0.05$, ANOVA.

Hypoxia studies. Fetal $\mathrm{PaO}_{2}$ decreased significantly during exposure to the hypoxic gas mixture at 10 and $20 \mathrm{~min}$ (Table 2). The decrement in $\mathrm{pO}_{2}$ was comparable in all the animals exposed to hypoxia ( $p>0.05$, ANOVA). There was no change in either the saline control group $(25 \pm 1 \mathrm{~mm} \mathrm{Hg})$ or the naloxone alone control group ( $22 \pm 1 \mathrm{~mm} \mathrm{Hg}$ ) when compared to baseline levels.

Figure 2 shows the epinephrine levels at 10 and 20 min after hypoxia alone and hypoxia plus naloxone at four different dosages. All epinephrine responses during hypoxia were significantly greater than the responses after treatment with saline or naloxone alone. Plasma epinephrine levels during the $0.1 \mathrm{mg} / \mathrm{kg}$ naloxone dose were significantly greater than with hypoxia alone $(p<$ 0.05 , two-way ANOVA). The geometric mean epinephrine level by $20 \mathrm{~min}$ was $5366 \pm 3144 \mathrm{pg} / \mathrm{ml}$ during hypoxia with $0.1 \mathrm{mg} /$ $\mathrm{kg}$ naloxone versus $997 \pm 981 \mathrm{pg} / \mathrm{ml}$ at $20 \mathrm{~min}$ during hypoxia alone. The plasma norepinephrine levels at 10 and 20 min after hypoxia alone and hypoxia plus naloxone at four different dosages are shown in Figure 3. As noted for epinephrine responses, all norepinephrine responses during hypoxia were significantly greater than those after treatment with saline alone or naloxone alone. There were no differences in plasma norepinephrine responses among the different naloxone treatment groups during hypoxia.

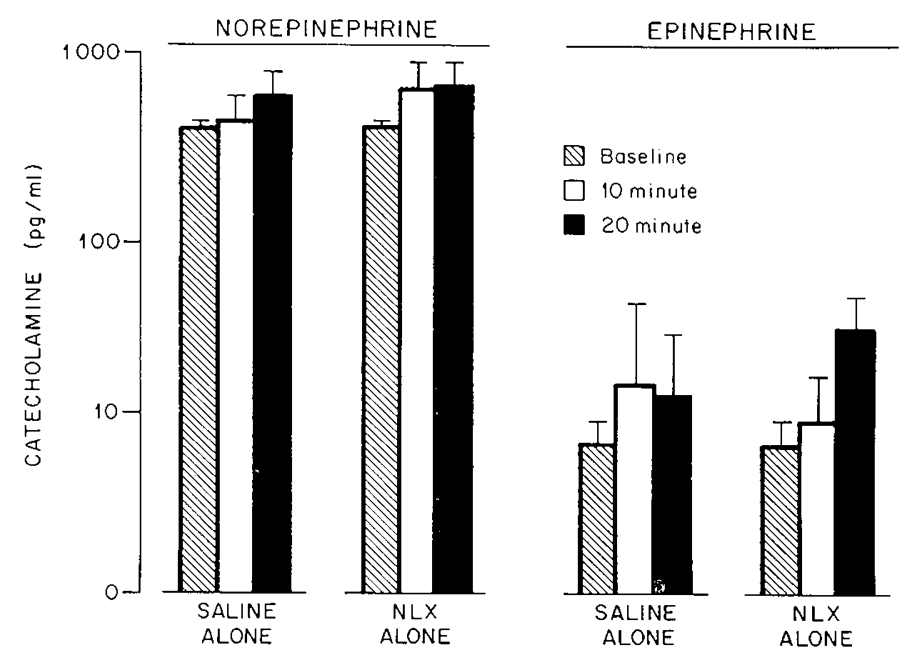

Fig. 1. Catecholamine levels during saline and naloxone control infusions. Values expressed as mean \pm SEM.

Table 1. Baseline biophysical and hormonal data for all study groups*

\begin{tabular}{|c|c|c|c|c|c|c|c|}
\hline Study condition & $\begin{array}{l}\text { Gestational } \\
\text { age (days) }\end{array}$ & $\mathrm{pH}$ & $\begin{array}{c}\mathrm{pO}_{2} \\
(\mathrm{~mm} \mathrm{Hg})\end{array}$ & $\begin{array}{l}\text { Norepinephrine } \\
(\mathrm{pg} / \mathrm{ml})\end{array}$ & $\begin{array}{l}\text { Epinephrine } \\
(\mathrm{pg} / \mathrm{ml})\end{array}$ & $\begin{array}{c}\text { HR } \\
\text { (bpm) }\end{array}$ & $\begin{array}{c}\text { Systolic } \\
\text { blood } \\
\text { pressure } \\
(\mathrm{mm} \\
\mathrm{Hg})\end{array}$ \\
\hline Saline control & $127 \pm 2$ & $7.37 \pm 0.01$ & $25 \pm 2$ & $353 \pm 47$ & $10 \pm 7$ & $171 \pm 3$ & $74 \pm 2$ \\
\hline Naloxone control & $128 \pm 2$ & $7.35 \pm 0.01$ & $22 \pm 1$ & $398 \pm 88$ & $5 \pm 3$ & $170 \pm 8$ & $79 \pm 4$ \\
\hline Hypoxia alone & $131 \pm 3$ & $7.35 \pm 0.01$ & $21 \pm 1$ & $432 \pm 74$ & $9 \pm 4$ & $163 \pm 4$ & $79 \pm 4$ \\
\hline Naloxone $(0.5 \mathrm{mg} / \mathrm{kg})$ & $130 \pm 1$ & $7.35 \pm 0.01$ & $23 \pm 1$ & $419 \pm 67$ & $8 \pm 3$ & $164 \pm 6$ & $77 \pm 3$ \\
\hline Naloxone $(1.0 \mathrm{mg} / \mathrm{kg})$ & $132 \pm 3$ & $7.35 \pm 0.01$ & $21 \pm 1$ & $405 \pm 53$ & $7 \pm 4$ & $157 \pm 3$ & $77 \pm 2$ \\
\hline Naloxone $(2.0 \mathrm{mg} / \mathrm{kg})$ & $132 \pm 1$ & $7.36 \pm 0.01$ & $21 \pm 1$ & $457 \pm 56$ & $7 \pm 4$ & $161 \pm 6$ & $74 \pm 2$ \\
\hline
\end{tabular}

* Biophysical values expressed as mean \pm SEM. Catecholamines expressed as geometric mean \pm SEM. 
Table 2. Biophysical data for fetal sheep during control and hypoxia protocols (mean \pm SEM)

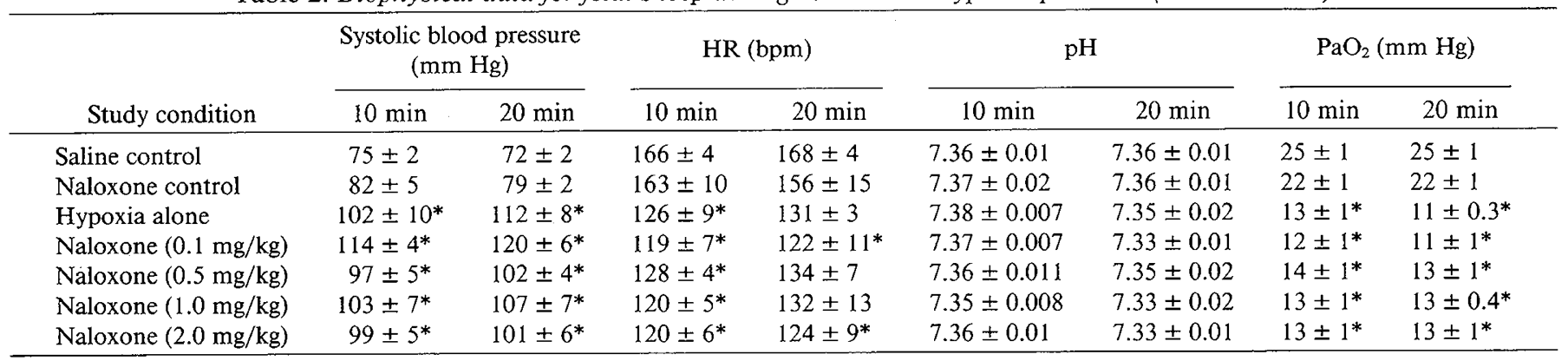

* Significantly different from baseline values $(p<0.05)$.

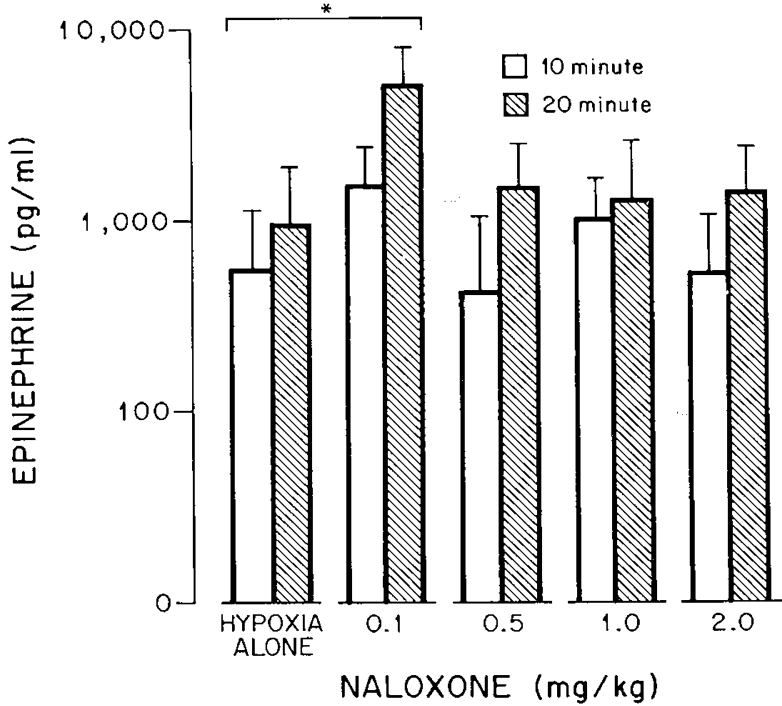

Fig. 2. Epinephrine levels during hypoxia. Values expressed as mean \pm SEM. ${ }^{*} p<0.05$ when compared by two-way ANOVA.

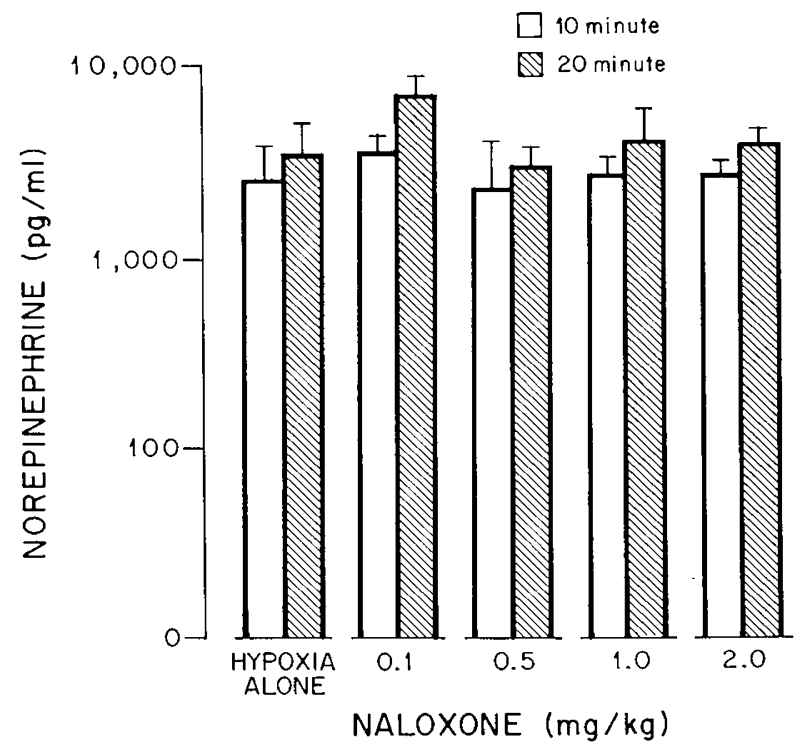

Fig. 3. Norepinephrine levels during hypoxia. Values expressed as mean \pm SEM.

By 10 min of hypoxia, mean systolic blood pressure had risen significantly in all treatment groups when compared to saline or naloxone control animals (hypoxia $102 \pm 10 \mathrm{~mm} \mathrm{Hg}$, saline control $75 \pm 2 \mathrm{~mm} \mathrm{Hg}$, naloxone control $82 \pm 5 \mathrm{~mm} \mathrm{Hg}$ ) and this effect was still apparent after 20 min of hypoxia (hypoxia
$112 \pm 8 \mathrm{~mm} \mathrm{Hg}$, saline control $72 \pm 2 \mathrm{~mm} \mathrm{Hg}$, naloxone control $79 \pm 2 \mathrm{~mm} \mathrm{Hg}$ ). The blood pressure in animals treated with hypoxia plus naloxone did not differ significantly from animals treated with hypoxia alone (Table 2).

The HR values at 10 min were significantly lower in all hypoxic fetuses $(123 \pm 3 \mathrm{bpm})$ than in the saline control group (166 \pm 4 $\mathrm{bpm})$ or the naloxone control group $(163 \pm 10 \mathrm{bpm})$. By $20 \mathrm{~min}$, only HR in the hypoxia plus $0.1 \mathrm{mg} / \mathrm{kg}$ naloxone group (mean HR of $122 \pm 11 \mathrm{bpm}$ ) and the hypoxia plus $2.0 \mathrm{mg} / \mathrm{kg}$ naloxone group (mean HR of $124 \pm 9 \mathrm{bpm}$ ) were significantly lower than the normal saline control group (168 $\pm 4 \mathrm{bpm})$.

Despite the induced hypoxemia, there were no statistical differences in systemic $\mathrm{pH}$ when comparing the different treatment groups at 10 and $20 \mathrm{~min}$.

\section{DISCUSSION}

Herein we demonstrated a marked augmentation in plasma epinephrine response when fetal sheep were treated with a 0.1 $\mathrm{mg} / \mathrm{kg}$ bolus and $0.1 \mathrm{mg} / \mathrm{kg} / \mathrm{h}$ infusion of naloxone during hypoxemia. We noted both fetal hypertension and reflex bradycardia associated with hypoxia. The increase in blood pressure in the low dose naloxone group was greater than any other treatment group or the hypoxia control but this difference was just at the level of statistical significance. It is likely that more repetitive measures of blood pressure would have demonstrated a statistically significant difference. The continuing bradycardia in the low dose naloxone group probably represents a reflex response to the sustained elevation in blood pressure. Previous studies have shown a decrease in HR in animals exposed to hypoxia $(25,26)$. Moreover, the use of naloxone during hypoxia has been shown to further exaggerate this bradycardic response (25). Atropine has been shown to reverse this effect (25). Under normoxemic conditions, naloxone alone did not affect blood pressure, $\mathrm{HR}$, or plasma catecholamine levels.

The role of opiate peptides as modulators of sympathoadrenal activity has been the subject of recent investigations. The opiate peptides and their receptors have been identified in CNS areas important for cardiovascular and respiratory control (16) as well as in sympathetic ganglia (27) and the adrenal medulla (28) of many species. This distribution suggests possible interactions with the sympathoadrenal system. In sympathetic ganglia, opiate peptides inhibit norepinephrine release through presynaptic inhibition of cholinergic transmission probably through reduced acetylcholine release $(17,18)$. Opiate peptides also reduce the response of peripheral organs to electrical field stimulation from a presumed receptor-mediated inhibition of acetylcholine and norepinephrine release (29). Adrenal medullary cells in vitro release catecholamines in response to cholinergic stimulation. Endogenous opiates inhibit this response and are effective at concentrations comparable to those observed during physiologic states (19). Endogenous opiates in the central nervous system also inhibit sympathoadrenal activity (21) and this effect can be blocked by CNS doses of opiate receptor blockers which have no effect when administered peripherally $(30,31)$. 
In vivo, plasma catecholamines have been measured before and after induced hemorrhage in adult rabbits and after naloxone administration. Naloxone caused a nearly $100 \%$ increase in circulating norepinephrine and return of blood pressure to normal with a smaller increase in plasma epinephrine (32). In adult humans with septic shock, naloxone administration evoked a 10 -fold increase in plasma epinephrine levels associated with improvements in circulatory function (33). Similar improvements in blood pressure and peripheral perfusion after naloxone have been observed in septic newborn humans $(34,35)$. In adult rats, the beneficial effects of naloxone during hemorrhagic shock are blocked by adrenalectomy ( 31 ). In contrast, fentanyl, a potent opiate agonist, causes a dose-dependent inhibition of plasma norepinephrine and epinephrine in humans $(36,37)$ and adult dogs (38) as well as decreases in HR, blood pressure, and cardiac output. However, the effects of opiate peptides are complex and their excitatory or inhibitory effects depend on the site of administration, the concomitant use of anesthesia, the species studied, the type of receptor affected, and the dose administered (16). In contrast to the present results, intracisternal administration of $\beta$ endorphin in unanesthetized rats is associated with an increase in circulating norepinephrine, epinephrine, and dopamine (39). Moreover, both pressor and depressor responses have been observed in response to the same opiate peptide injected into neighboring paraventricular regions less than $1 \mathrm{~mm}$ apart (40).

An important finding herein was the apparent differential activation by naloxone of epinephrine release from the adrenal gland. Previous studies have also suggested both differential epinephrine (33) and norepinephrine (32) responses. Whether these represent species differences or are due to differences in experimental models is unclear. There are well-described maturational changes in control of adrenal function during fetal and newborn life. Adrenal catecholamine release during hypoxia has been shown to occur by two separate mechanisms. A nonneurogenic mechanism, independent of splanchnic innervation, is seen in fetal sheep up until the last 20 days of intrauterine gestation (41) and in newborn rats up to 8 days postnatally (8). With the development of splanchnic nerve innervation, there is an increase in the magnitude of catecholamine release and an increase in the proportion of epinephrine. It is possible that the selective epinephrine response to naloxone during hypoxia reflects the level of maturation attained by the fetal sheep at the time of study or that hypoxia may selectively result in an opiate peptide "limit" on adrenal epinephrine release. Whether there would be a difference in the magnitude of response to naloxone or in the selective release of either norepinephrine or epinephrine during very early fetal life compared to term animals is not answered by our study. Additional studies are needed to further elucidate the physiologic role of the opiate peptides and the maturational changes that occur in the sympathoadrenal system.

Herein we observed a marked dose response difference. Naloxone at a low dosage was shown to potentiate the plasma epinephrine response to hypoxia whereas no effect was observed at higher doses. Multiple opiate receptor subtypes are now recognized $(40,42)$. Whereas overlap exists because endogenous opiates and pharmacologic agents have only relative selectivity for one receptor over another, some generalizations do exist. $\mathrm{Mu}$-receptors generally mediate analgesic and vasodepressive effects while $\delta$-receptors mediate pressor-type cardiovascular effects. Naloxone is a competitive opiate receptor antagonist (42) with approximately 10 -fold greater affinity for $\mu$ than $\delta$ receptors $(43,44)$. Thus our results are consistent with the interpretation that naloxone at the lowest dose was antagonizing $\mu$-receptormediated inhibition of catecholamine release. At the highest dose naloxone may have been blocking a $\delta$-receptor-mediated increase in sympathoadrenal activity and catecholamine release. This is in agreement with previous data on the effect of high dose naloxone on plasma catecholamines during brief periods of hypoxia induced by umbilical cord occlusion in sheep (26).

In conclusion, we found hypoxia to be a significant stimulus for epinephrine release in fetal sheep and that low level naloxone treatment augments this release. Our data suggest that hypoxia increases endogenous opiate peptide release and that opiate peptides in turn affect the cardiovascular response of fetal sheep by inhibiting the sympathoadrenal system. Further studies are necessary to clarify the mechanisms involved as well as the physiologic importance of the interaction of these two systems.

\section{REFERENCES}

1. Cohen WR, Piasecki GJ, Jackson BT 1982 Plasma catecholamines during hypoxemia in fetal lamb. Am J Physiol 243:R520-R525

2. Gunn TR, Johnston BM, Iwamoto HS, Fraser M, Nicholls MG, Gluckman PD 1985 Haemodynamic and catecholamine responses to hypothermia in the fetal sheep in utero. J Dev Physiol 7:241-249

3. Brace RA, Cheung CY 1986 Fetal cardiovascular and endocrine responses to prolonged fetal hemorrhage. Am J Physiol 251:R417-R424

4. Eliot RJ, Klein AH, Glatz TH, Nathanielsz PW, Fisher DA 1981 Plasma norepinephrine, epinephrine, and dopamine concentrations in maternal and fetal sheep during spontaneous parturition and in premature sheep during cortisol-induced parturition. Endocrinology 108:1678-1682

5. Lagercrantz H, Bistoletti $P 1973$ Catecholamine release in the newborn infant at birth. Pediatr Res 11:889-893

6. Padbury JF, Roberman B, Oddie TH, Hobel CJ, Fisher DA 1982 Fetal catecholamine release in response to labor and delivery. Obstet Gynecol 60:607-611

7. Padbury JF, Agata Y, Ludlow J, Ikegami M, Baylen B, Humme J 1987 The effect of fetal adrenalectomy on catecholamine release and physiologic adaptation at birth in sheep. J Clin Invest 80:1096-1103

8. Seidler FJ, Slotkin TA 1985 Adrenomedullary function in the neonatal rat: responses to acute hypoxia. J Physiol 358:1-16

9. Stark RI, Wardlaw SL, Daniel SS 1986 Characterization of plasma $\beta$-endorphin immunoactivity in the fetal lamb: effects of gestational age and hypoxia. Endocrinology 119:755-761

10. Sankaran K, Hindmarsh KW, Watson VG 1983 Hypoxic-ischemic encephalopathy and plasma $\beta$-endorphin. Dev Pharmacol Ther 7:377-383

11. Chernick V, Craig RJ 1982 Naloxone reverses neonatal depression caused by fetal asphyxia. Science 216:1252-1253

12. Klein RL, Yabuno N, Peeler DF, Thureson-Klein A, Douglas BH, Duff RB, Clayton WE 1986 Adrenal enkephalin and catecholamine contents following subarachnoid hemorrhage in cats. Neuropeptides 8:143-158

13. Farrell LD, Harrison TS, Demers LM 1983 Immunoreactive met-enkephalin in the canine adrenal; response to acute hypovolemic stress. Proc Soc Exp Biol Med 173:515-518

14. Kofinas GD, Kofinas AD, Tavakoli FM 1985 Maternal and fetal $\beta$-endorphin release in response to the stress of labor and delivery. Am J Obstet Gynecol 152:56-59

15. Fettes I, Fox J, Kuzniak S, Shime J, Gare D 1984 Plasma levels of immunoreactive $\beta$-endorphin and adrenocorticotropic hormone during labor and delivery. Obstet Gynecol 64:359-362

16. Holaday JW 1983 Cardiovascular effects of endogenous opiate systems. Ann Rev Pharmacol Toxicol 23:541-594

17. Konishi S, Tsunoo A, Otsuka M 1979 Enkephalins presynaptically inhibit cholinergic transmission in sympathetic ganglia. Nature 282:515-516

18. Konishi S, Tsunoo A, Otsuka M 1981 Enkephalin as a transmitter for presynaptic inhibition in sympathetic ganglia. Nature 294:80-82

19. Kumakura K, Karoum F, Guidotti A, Costa E 1980 Modulation of nicotine receptors by opiate receptor agonists in cultured adrenal chromaffin cells. Nature 283:489-492

20. Chantry CJ, Seidler FJ, Slotkin TA 1982 Non-neurogenic mechanism for reserpine-induced release of catecholamines from the adrenal medulla of neonatal rats: possible modulation by opiate receptors. Neuroscience 7:673678

21. Dashwood MR, Feldberg W 1979 Central inhibitory effect of released opiate peptides on adrenal medulla, revealed by naloxone in the cat. $J$ Physiol 300:22-23

22. Padbury JF, Agata Y, Polk DH, Wang DL, Callegari CC 1987 Neonatal Adaptation: naloxone increases the catecholamine surge at birth. Pediatr Res 21:590-593

23. Peuler JD, Johnson GA 1977 Simultaneous single isotope radioenzymatic assay of plasma norepinephrine, epinephrine and dopamine. Life Sci 21:625636

24. Robillard JE, Matson JR, Sessions C, Smith FG Jr 1979 Developmental aspects of renal tubular reabsorption of water in the lamb fetus. Pediatr Res 13:11721176

25. LeGamma EF, Itskovitz J, Rudolph AM 1982 Effects of naloxone on fetal circulatory responses to hypoxemia. Am J Obstet Gynecol 143:933-937

26. Lewis AB, Ferry DA 1986 Effect of endogenous opioid blockade on fetal cardiovascular and sympathoadrenal responses to hypoxemia induced by umbilical cord constriction. Biol Neonate 50:171-176

27. Schultzberg M, Hokfelt T, Lundberg JM, Terenius L, Elfvin L-G, Elde R 1978 Enkephalin-like immunoreactivity in nerve terminals in sympathetic ganglia and adrenal medulla and in adrenal medullary gland cells. Acta Physiol Scand 103:475-477 
28. Schultzberg M, Lundberg JM, Hokfelt T, Terenius L, Brandt J, Elde RP, Goldstein M 1978 Enkephalin-like immunoreactivity in gland cells and nerve terminals of the adrenal medulla. Neuroscience 3:1169-1186

29. Ruth JA, Doerr AL, Eiden LE $1984\left[\mathrm{Leu}^{\mathrm{s}}\right]$ enkephalin inhibits norepinephrineinduced contraction of rat aorta. Eur $\mathbf{J}$ Pharmacol 105:189-19

30. Janssen HF, Lutherer LO 1980 Ventriculocisternal administration of naloxone protects against severe hypotension during endotoxin shock. Brain Res 194:608-612

31. Holaday JW, D'Amato RJ, Ruvio BA, Feuerstein G, Faden AI 1983 Adrenalectomy blocks pressor responses to naloxone in endotoxic shock: evidence for sympathomedullary involvement. Circ Shock 11:201-210

32. Schadt JC, Gaddis RR 1985 Endogenous opiate peptides may limit norepinephrine release during hemorrhage. J Pharmacol Exp Ther 232:656-660

33. Hughes GS Jr 1984 Naloxone and methylprednisolone sodium succinate enhance sympathomedullary discharge in patients with septic shock. Life Sci 35:2319-2325

34. Catterton Z, Howick J, Oliver S 1984 Naloxone in neonatal septic shock. Clin Res 32:898

35. Furman WL, Menke JA, Barson WJ, Miller RR 1984 Continuous naloxone infusion in two neonates with septic shock. J Pediatr 105:649-651

36. Anand KJS 1987 Randomized trial of fentanyl anaesthesia in preterm babies undergoing surgery: effects on the stress response. Lancet 1:243-247
37. Pathak KS, Anton AH, Sutheimer CA 1985 Effects of low-dose morphine and fentanyl infusions on urinary and plasma catecholamine concentrations during scoliosis surgery. Anesth Analg 64:509-514

38. Flacke JW, Flacke WE, Bloor BC, Olewine BS 1983 Effects of fentanyl, naloxone, and clonidine on hemodynamics and plasma catecholamine levels in dogs. Anesth Analg 62:305-313

39. Van Loon GR, Appel NM, Ho D $1981 \beta$-Endorphin-induced increases in plasma epinephrine, norepinephrine and dopamine in rats: inhibition of adrenomedullary response by intracerebral somatostatin. Brain Res 212:207214

40. Feuerstein G, Faden AI 1982 Differential cardiovascular effects of $\mu, \sigma$ and $\kappa$ opiate agonists at discrete hypothalamic sites in the anesthetized rat. Life Sci 31:2197-2200

41. Comline RS, Silver M 1961 The release of adrenaline and noradrenaline from the adrenal glands of the foetal sheep. J Physiol 156:424-444

42. Paterson SJ, Robson LE, Kosterlitz HW 1983 Classification of opioid receptors. Br Med Bull 39:31-36

43. Gordon FJ 1986 Central opioid receptors and baroreflex control of sympathetic and cardiovascular function. $J$ Pharmacol Exp Ther 237:428-436

44. Cohen ML, Shuman RT, Osborne JJ, Gesellchen PD 1986 Opioid agonist activity of ICI 174864 and its carboxypeptidase degradation product, LY281217. J Pharmacol Exp Ther 238:769-772 